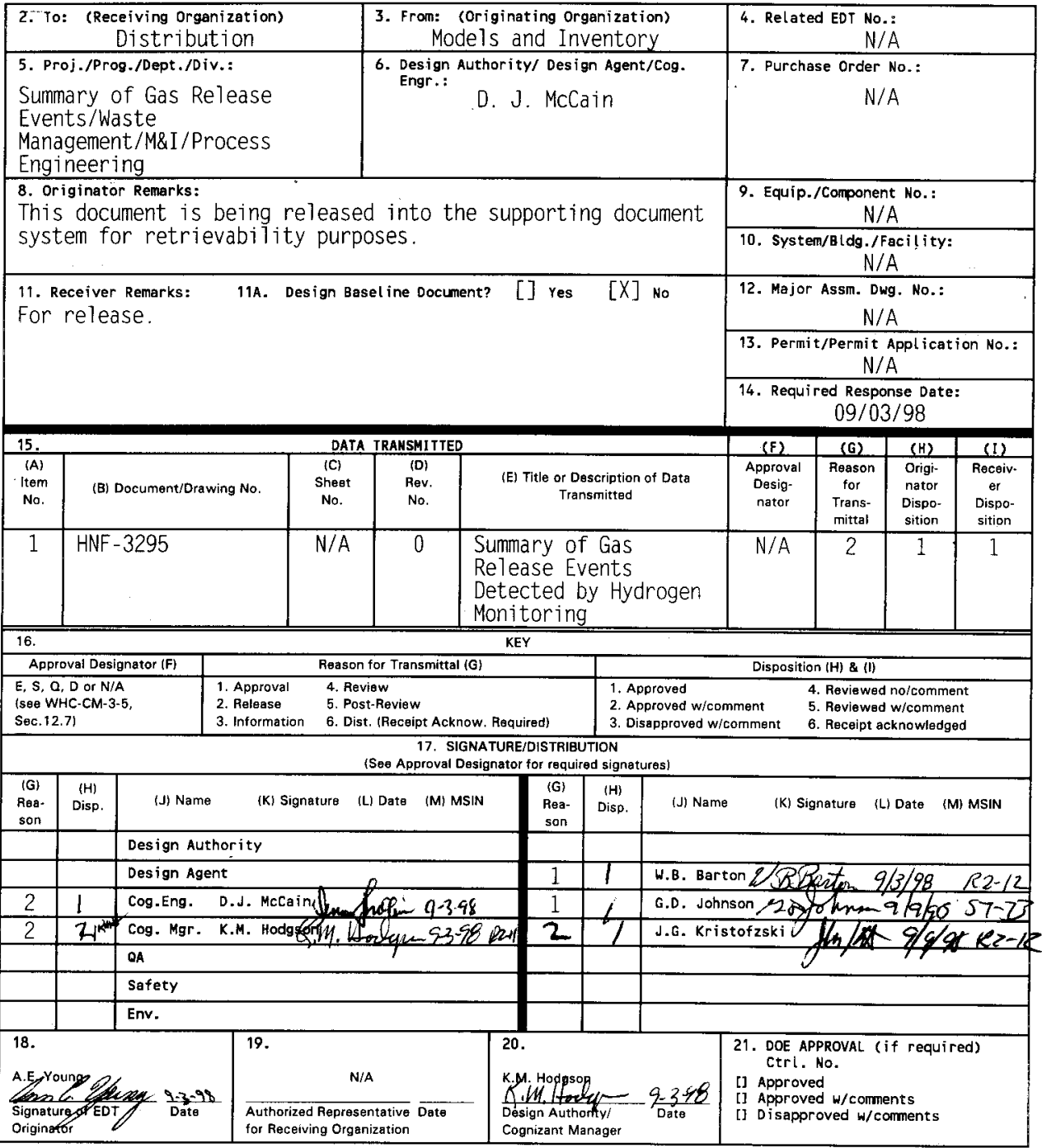




\section{Summary of Gas Release Events Detected By Hydrogen Monitoring}

D. J. McCain

Lockheed Martin Hanford, Corp., Richland, WA 99352

U.S. Department of Energy Contract DE-AC06-96RL13200

EDT/ECN: EDT-622474 UC: 2070

Org Code: 7A110 Charge Code: N22DB

B\&R Code: EW 3120074 Total Pages: 9

Key words: Flammable Gas, SHMS. Hydrogen, GRE, Gas Release Event

Abstract: This paper summarizes the results of monitoring tank headspace for flammable gas release events. In over 40 tank years of monitoring the largest detected release in a single-shell tank is 2.4 cubic meters of Hydrogen. In the double-shel1 tanks the largest release is 19.3 cubic meters except in SY-101 pre mixer pump installation condition.

TRADEMARK DISCLAIMER. Reference herein to any specific commercial product, process, or service by trade name, trademark, manufacturer, or otherwise, does not necessarily constitute or imply its endorsement, recommendation, or favoring by the United States Govermment or any agency thereof or its contractors or subcontractors.

Printed in the United States of America. To obtain copies of this document, contact: Document Control Services, P.0. Box 950, Mailstop H6-08, Richland WA 99352, Phone (509) 372-2420;

Fax (509) 376-4989.
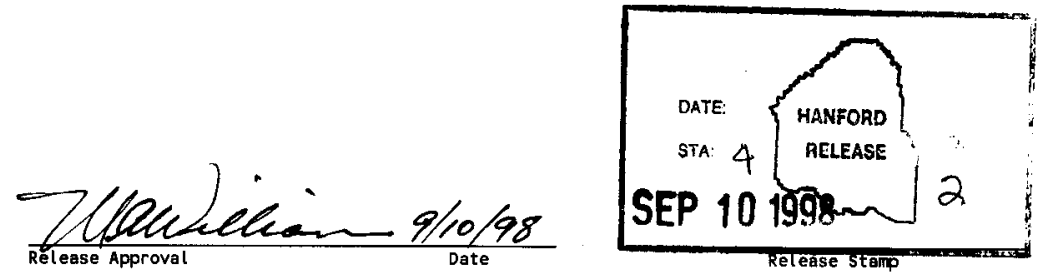

Approved for Public Release 
HNF-3295

Revision 0

\section{Summary of Gas Release Events Detected by Hydrogen Monitoring}

D. J. McCain

W. B. Barton

Lockheed Martin Hanford Corp.

Date Published

September 1998

Prepared for the U.S. Department of Energy

FUOR DANIEL MANPOR, INC.

P.O. Box 1000

Richland, Washington

Hanford Management and Integration Contractor for the

U.S. Department of Energy under Contract OE-ACO6-96RL13200

Approved for Public Release; Further Dissemination Unlimited 
HNF-3295, Rev. 0

\section{Summary of Gas Release Events Detected by Hydrogen Monitoring}

This paper summarizes the results of monitoring tank headspace for flammable gas release events (GREs) using the Standard Hydrogen Monitoring System (SHMS). SHMS have been installed on the tanks which are most likely to experience a GRE, such as Flammable Gas Watch List tanks. These results are briefly compared to the assumptions on GREs which were used in the preparation of the Basis for Interim Operation (BIO).

The SHMS provide direct measurement of the hydrogen concentration in the tank headspace. These measurements provide a means of identifying GREs which are much smaller than those found through rapid decreases in surface level in tanks. In addition, they provide a capability to track the rate of gas release and progress of a GRE.

The SHMS is designed to monitor hydrogen at relatively high concentrations compared to the background concentrations in the tanks. The Whittaker cell is rated with a minimum detection limit of about 2300 parts per million by volume hydrogen ( $\mathrm{ppmv}_{2}$ ). Grab sampling has shown that the instruments retain reasonable accuracy down to the $100 \mathrm{ppmv} \mathrm{H}_{2}$ range. However, at these levels some drift is seen in the instrument readings. The analyst must discriminate among the normal variability, drift, and GREs. This process is somewhat subjective and informal review has shown that different analysts may interpret small events differently. GREs, greater than about $1000 \mathrm{ppmv} \mathrm{H}_{2}$ increase, are easily separated from these effects. Since most of the events reported are small events, the numbers shown should be interpreted as estimates with an uncertainty of about 50 percent.

The information derived from the SHMS are presented in the table. For an explanation of the contents of each column see the notes following the table. Included in the table is information on the waste volume and principal waste type as identified by Agnew (1997).

GRE modeling reported in Appendix $\mathrm{E}$ of the $\mathrm{BIO}$, is based on an assumption of a bounding GRE releasing up to 25 percent of the retained gas in the tank. This assumption was applied to both double-shell tank (DST) and single-shell tank (SST) waste configurations. The SHMS results and current models do not support such large releases from SSTs. The table shows that the largest recorded hydrogen release in a SST is only 2.4 cubic meters, less than $8 \%$ of the LFL, in over 40 tank years of SHMS monitoring data. Releases of this magnitude do not render the tank headspace flammable and dissipate quickly.

DST releases are both larger and more rapid than SST gas release events. However, the maximum hydrogen release in a DST, other than tank 241-SY-101, occurred in tank 241-AN-105 and reached a concentration of 46 percent of the Lower Flammability limit (LFL). All other DST hydrogen releases monitored, since the SHMS were installed, did not exceed 25 percent LFL. 
HNF-3295, Rev. 0

This is consistent with the current understanding of the physical phenomena which govern the buoyant displacement type GRE.

It should also be noted that some SSTs have not shown any evidence of GREs since the SHMS were installed. 
HNF-3295, Rev. 0

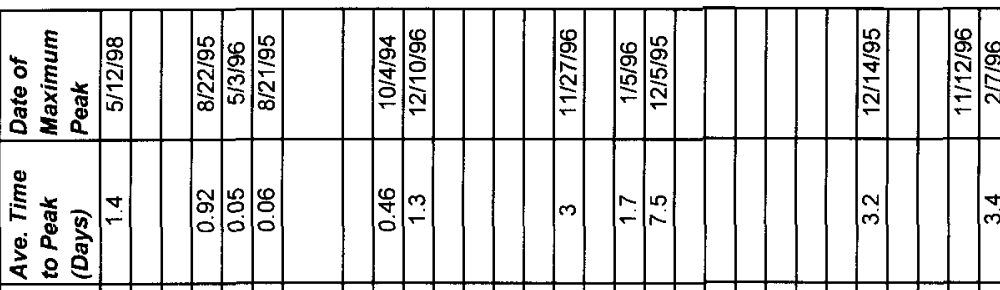

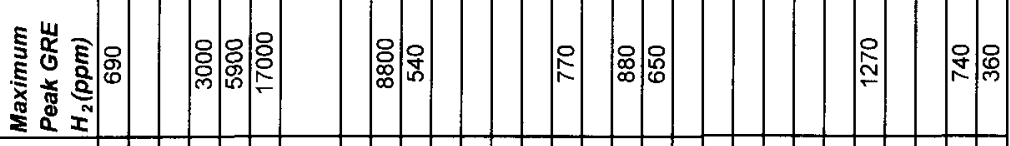

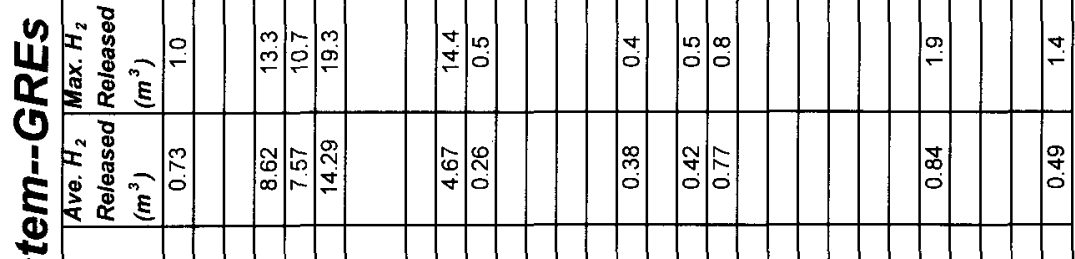

$n$
S \begin{tabular}{l}
$\mathbf{0}$ \\
\hline
\end{tabular}

0

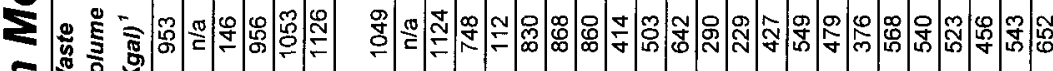
C.

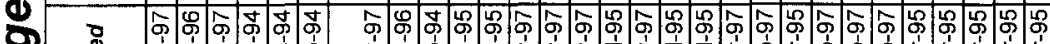

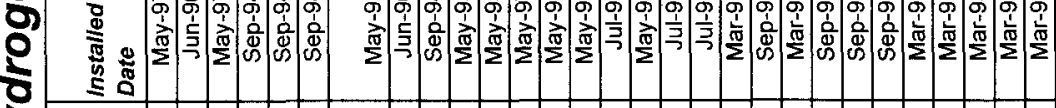

210 ó

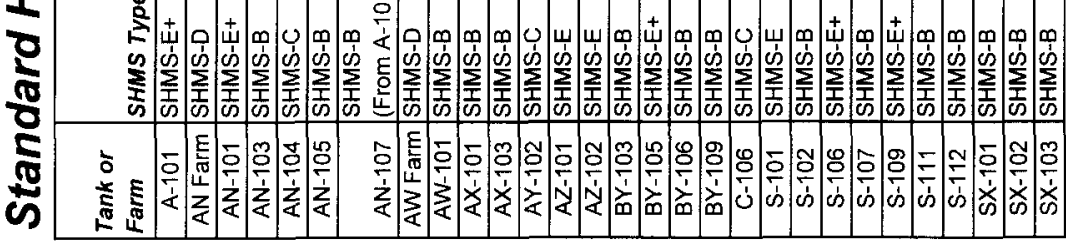




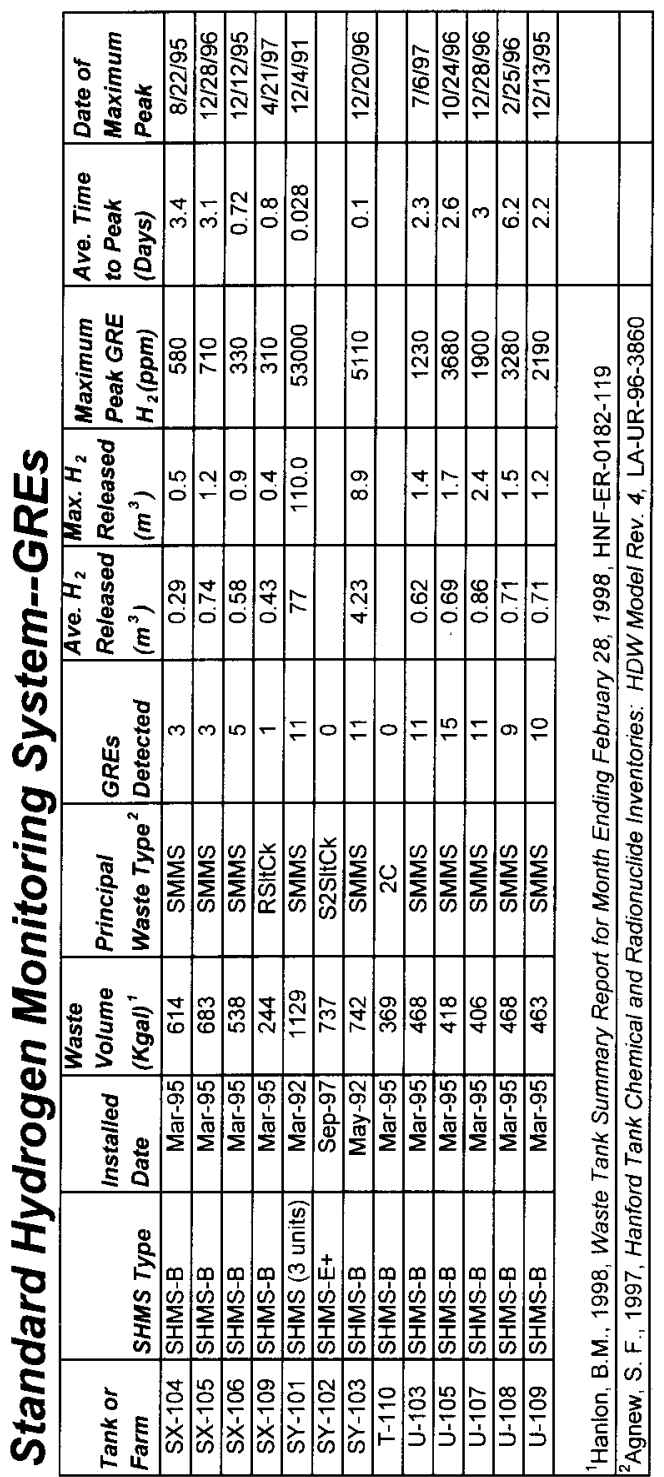


HNF-3295, Rev. 0

\section{Chart Column Explanations}

1. Tank or Farm--SHMS cabinets can be placed directly on the riser of an underground tank or on a farm exhaust system. The list includes tanks whose SHMS are not currently operational, but have significant data.

2. SHMS Type--Four main configurations for Whittaker electrochemical cells:

B. Specifically monitor for hydrogen. Environmentally controlled enclosures with two cells and a grab sample station. Data goes to Tank Monitoring and Control System (TMACS), where installed, and locally on a strip chart recorder.

C. Specifically monitor for hydrogen. Environmentally controlled enclosures with two cells, a dual column gas chromatograph (for low hydrogen concentrations) and a grab sample station. Data goes to TMACS and the Hanford Local Area Network (HLAN), where installed, and locally on a personal computer (PC) and strip chart recorder.

D. Located on farm exhausts to monitor for hydrogen and ammonia.

Environmentally controlled enclosures with two cells, a grab sample station and a photo-acoustic infra-red (IR) analyzer. Data goes to TMACS and HLAN, where installed, and locally on a PC and strip chart recorder. May be used as a "B" type without the installation of the IR analyzer.

E. Analyze for hydrogen, nitrous oxide, methane and ammonia. Data goes to TMACS and HLAN, where installed, and locally on a PC and strip chart recorder. Environmentally controlled enclosures with two cells, a grab sample station, a dual column gas chromatograph (GC) and a photo-acoustic IR analyzer. Data goes to TMACS and HLAN, where installed, and locally on a PC and strip chart recorder. May be used as a "B" type without the analytical instruments.

3. Installed Date--most recent installation listed. It should be noted that data collection did not always commence at the completion of installation. Calibration and acceptance by the plant were required before the SHMS were turned on. For those cabinets installed in 1997, data collection did not typically start until after October, 1997.

4. Waste Volume (Kgal)--volume of solids and liquids within tank as provided in reference source.

5. Principal Waste Type--review of process records and flow diagrams as well as other documents has allowed classification of high-level wastes into distinct types. The referenced source details this classification and lists principal constituents.

6. GREs Detected-- Results of Vapor Space Monitoring of Flammable Gas Watch List Tanks, HNF-SD-TI-797, is a report that lists the gas release events since monitoring 
HNF-3295, Rev. 0

began. It is updated annually and is currently in Revision 2, dated September 18, 1997. All information for this column originated in the referenced report or in the 1998 data which will be reflected in the annual update of the report. The table reflects GREs through May 20, 1998.

7. Average and Maximum Hydrogen Released--each of the events reported in Item 6, above was reviewed for volume of hydrogen released. The maximum per event is listed, along with a simple mean volume for the events listed. Occasionally, not enough data is available for this calculation. The user should remember that these numbers are for hydrogen only and do not represent the total volume of gas released. To calculate total volume of gas released the hydrogen volume must be multiplied by the ratio of total gas to hydrogen. This ratio can be estimated either from the Retained Gas Sampler (RGS) data or tank headspace concentration data.

8. Maximum Peak GRE $\mathbf{H}_{2}$--raw data from the various SHMS type sources, listing peak height for each event in item 6.

9. Average time to peak--each peak manifests a rise and a remission in terms of ppm hydrogen. This measurement is taken from the initiation of an event until the maximum peak is measured.

10. Date of Maximum Peak--this date matches up with the peak in item 8, above. 
HNF-3295, Rev. 0

\section{References}

Agnew, S. F., 1997, Hanford Tank Chemical and Radionuclide Inventories: HDW Model Rev. 4, LA-UR-96-3860, Los Alamos National Laboratory, Los Alamos, New Mexico.

Hanlon, B. M., 1998, Waste Tank Summary Report for Month Ending February 28, 1998, HNF-ER-0182-119, Lockheed Martin Hanford Company, Richland, Washington.

Wilkins, N. E., 1997, Results of Vapor Space Monitoring of Flammable Gas Watch List Tanks, HNF-SD-TI-797, Rev. 2, Lockheed Martin Hanford Company, Richland, Washington. 


\begin{tabular}{|c|c|c|c|c|c|c|}
\hline \multicolumn{7}{|c|}{ DISTRIBUTION SHEET } \\
\hline \multirow{2}{*}{$\begin{array}{l}\text { To } \\
\text { Distribution }\end{array}$} & \multirow{2}{*}{\multicolumn{4}{|c|}{ Models and Inventory }} & \multicolumn{2}{|l|}{ Page 1 of 1} \\
\hline & & & & & \multicolumn{2}{|c|}{ Date $\quad 09 / 03 / 98$} \\
\hline \multirow{2}{*}{\multicolumn{5}{|c|}{$\begin{array}{l}\text { Project Title/Work Order } \\
\text { HNF-3295, Rev. 0, "Summary } \\
\text { Hydrogen Monitoring" }\end{array}$}} & \multirow{2}{*}{\multicolumn{2}{|c|}{$\begin{array}{ll}\text { EDT No. } & \text { EDT-622474 } \\
\text { ECN No. } & \text { N/A }\end{array}$}} \\
\hline & & & & & & \\
\hline \multicolumn{2}{|l|}{ Name } & MSIN & $\begin{array}{l}\text { Text } \\
\text { With } \\
\text { Al7 } \\
\text { Attach. }\end{array}$ & Text Only & $\begin{array}{l}\text { Attach./ } \\
\text { Appendix } \\
\text { Only }\end{array}$ & $\begin{array}{l}\text { EDT/ECN } \\
\text { On7y }\end{array}$ \\
\hline \multicolumn{7}{|l|}{$\begin{array}{l}\text { DE\&S Hanford, Inc. } \\
\text { R. E. Bauer } \\
\text { D. R. Bratzel } \\
\text { R. J. Cash } \\
\text { G. W. Gault } \\
\text { T. C. Geer } \\
\text { G. D. Johnson } \\
\text { C. E. Leach } \\
\text { Y. G. Noorani }\end{array}$} \\
\hline $\begin{array}{l}\text { U. S. Department of Energy - } \\
\frac{\text { Richland Field Office }}{\text { C.A. Groendyke }} \\
\text { G. M. Neath }\end{array}$ & & $\begin{array}{l}57-54 \\
57-54\end{array}$ & $\frac{\text { U. S. Department of Energy - }}{\text { Richland Field Office }}$ & & & \\
\hline $\begin{array}{l}\text { Lockheed Martin Hanford Corp. } \\
\text { S. A. Barker } \\
\text { W. B. Barton } \\
\text { T. A. Hu } \\
\text { N. W. Kirch } \\
\text { J. G. Kristofzski } \\
\text { D. J. McCain } \\
\text { M. A. Payne } \\
\text { D. A. Reynolds } \\
\text { T.C.S.R.C. }\end{array}$ & & $\begin{array}{l}\text { R2-11 } \\
\text { R2-11 } \\
\text { R2-11 } \\
\text { R2-11 } \\
\text { R2-12 } \\
\text { R2-11 } \\
\text { R2-58 } \\
\text { R2 }-11 \\
\text { R1 }-10\end{array}$ & $\begin{array}{l}x \\
x \\
x \\
x \\
x \\
x \\
x \\
x \\
x\end{array}$ & & & \\
\hline \multicolumn{3}{|l|}{ Lockheed Martin Services, Inc. } & $x$ & & & \\
\hline $\begin{array}{l}\text { MACTC } \\
\text { J.D. Bingham } \\
\text { D. C. Hedengren }\end{array}$ & & $\begin{array}{l}\mathrm{R} 2-11 \\
\mathrm{R} 2-11\end{array}$ & $\begin{array}{l}x \\
x\end{array}$ & & & \\
\hline $\begin{array}{l}\text { Pacific Northwest National Labo } \\
\text { J. W. Brothers } \\
\text { L. A. Mahoney } \\
\text { P. A. Meyer } \\
\text { C. W. Steward }\end{array}$ & tory & $\begin{array}{l}k 9-20 \\
k 7-15 \\
k 7-15 \\
k 7-15\end{array}$ & $\begin{array}{l}x \\
x \\
x \\
x\end{array}$ & & & \\
\hline$\frac{\text { Self-Employed }}{\text { J.M. Grigsby }}$ & & S7-14 & $x$ & & & \\
\hline
\end{tabular}

